\title{
THE INCIDENCE OF INCOMPLETE DESCENT OF THE TESTICLE AT BIRTH
}

\author{
BY \\ C. G. SCORER \\ From Hillingdon Hospital, Uxbridge
}

(RECEIVED FOR PLBLICATION JANUARY 17. 1956)

Descent of the testicle from the abdomen into the scrotum is known to occur at about the eighth month of foetal life. If the transition has not taken place at birth it may do so shortly after. It is said that movement can take place at any time up to puberty but very rarely afterwards.

Mothers, midwives and doctors are all aware that the scrotum of the newborn baby is usually well formed and contains both testicles. The proportion of infants in whom descent has failed or is retarded has apparently only once before been seriously studied. This paper records the results of examining over 1,700 infants in order to discover how often the testicle was undescended at birth. If the deformity was found the baby was seen again at intervals of a few weeks until descent was complete. The follow-up continues in a few instances where the testicle has not yet descended.

\section{Previous Observations}

Hofstatter (1912) examined 600 neonatal infants, 150 of whom were premature and 450 full-term. He found fully descended testicles in $68 \%$ of the former and $96 \%$ of the latter. He does not say, however, how he selected the infants for examination, nor does he mention at what precise age they were seen. In addition, his premature birth rate is obviously high in comparison with present British figures and, in fact, his definition of prematurity is a loose one, being based not upon the weight of the infant but upon its ability to thrive.

More recent writings do not always take note of Hofstatter's work and much confusion and contradiction appear. Counseller (1933) says, 'the testes are in their normal physiological position at birth in 90\% of infants', whereas Deming (1952) asserts that it is estimated that $1 \%$ of the testes is undescended at birth'. Debenham and Baines (1954) give the incidence of incomplete descent in infants as about one in twenty. None of these statements has any meaning as it stands, for clearly, the incidence of the condition depends upon the maturity of the infant at the time of examination.

\section{Conduct of the Investigation}

The boys examined in this series were seen in the maternity department of a general hospital. A visit was paid to the ward on two set days in each week and every boy who had been born during the previous three or four days was examined. If an infant was stillborn or died within the stated period, the body was examined in the hospital mortuary. No differentiation was made as to whether the birth was by natural forces or by caesarean section; all were included. In this way a complete and consecutive series was obtained.

Exception, however, had to be made in two small groups of cases. If a mother with her baby was transferred to another hospital, or sent to her own home, within the first four days of birth, no attempt was made to trace them; such a random loss of cases, amounting to 28 , would not appear to invalidate the accuracy of the results. Secondly, if a mother less than 28 weeks pregnant gave birth to a dead infant, examination was usually impracticable or impossible, for in such an instance, the foetus not being technically 'viable', it was not sent to the mortuary. On the other hand if the infant lived even for a short time it was transferred to the mortuary after death and seen there.

On rare occasions the mother and baby were sent to a nearby convalescent home. The babies were examined there but not until between the fourth and tenth days.

I examined each one of the infants myself, with the exception of 69 during the holiday month of August when the work was done by the gynaecological registrar. All stillbirths and neonatal deaths were seen by me, with the exception of four which were seen either by the paediatric registrar or by the 
hospital pathologist. Owing to the relative ease of examination it is improbable that any case of incomplete descent of the testicle was overlooked (Fig. 1).

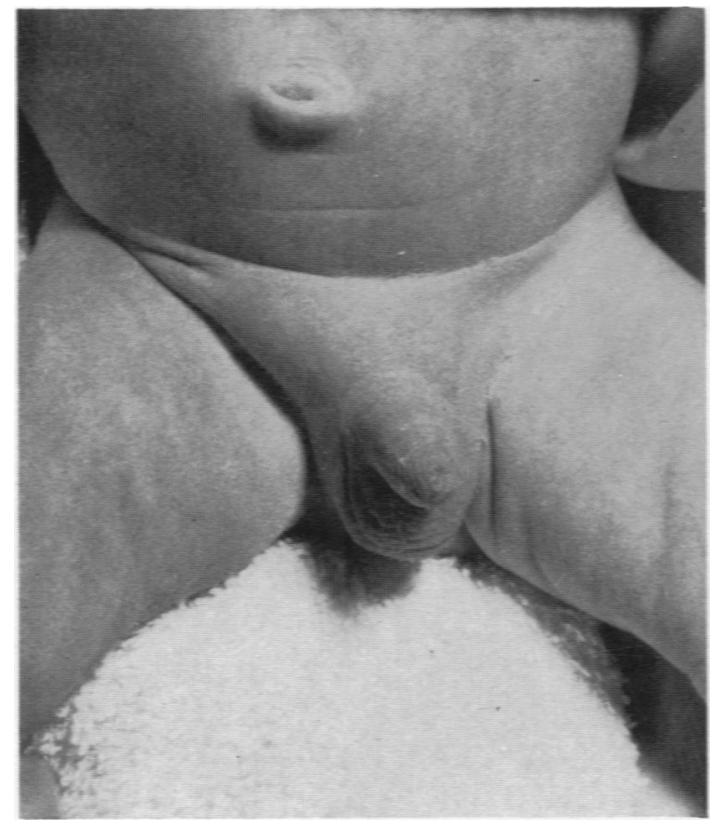

FiG. 1.-The appearance of the scrotum in a newborn infant weighing 5lb. 14oz. The right testicle presents as a swelling in the groin, the left is in the scrotum: the position of both was easily confirmed by palpation.

\section{Method of Examination}

It is a matter of common observation that the scrotum at birth is relatively larger than at any time in later life. In a full-term baby boy the length of the femur from pubic crest to knee joint is about $9 \mathrm{~cm}$.; the scrotum when in a relaxed condition may be drawn down $6 \mathrm{~cm}$. from the same point.

In addition, the infant at birth has comparatively little subcutaneous fat and the cremasteric reflex, so active in the young boy, is absent.

These three facts make examination of the testicle in the newborn an easy matter. No difficulty is found in deciding the position of the organ provided it is outside the external inguinal ring. With the thumb and forefinger the testis and epididymis, together of moderately firm consistency, can be held and gently drawn down a distance of between $4 \mathrm{~cm}$. and $6 \mathrm{~cm}$. from the pubic crest, sometimes even further. This distance can be measured with a ruler (Fig. 2 and Fig. 3).

\section{Criterion of Incomplete Descent}

The criterion of complete descent has been arbitrarily defined to be when the testicle can be drawn down to a distance of $4 \mathrm{~cm}$. or more from

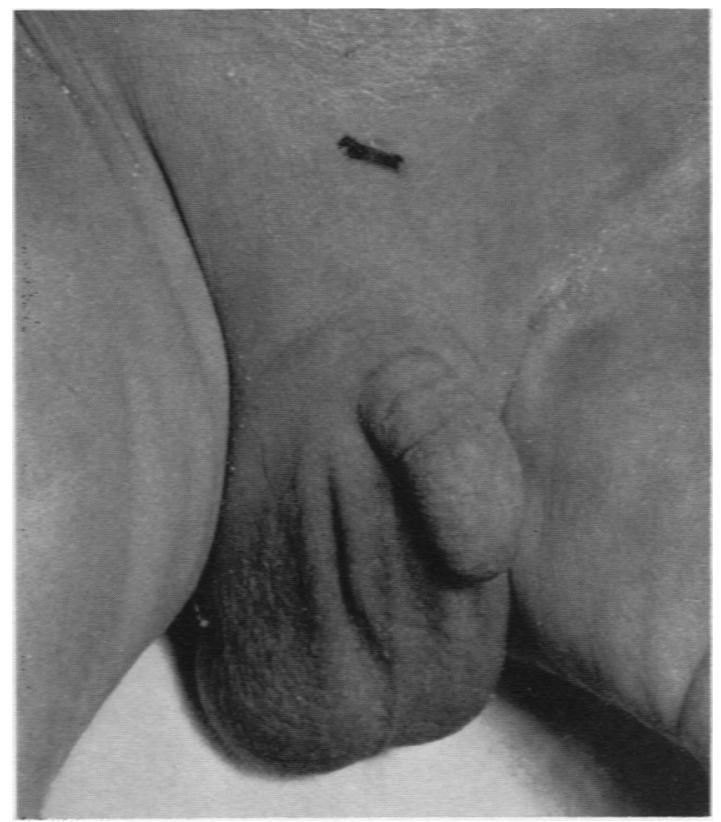

FiG. 2.-Scrotum of a full-term male infant, birth weight $7 \mathrm{lb}$. $20 \mathrm{z}$ The black mark denotes the pubic crest.

the pubic crest. Any figure less than this was incomplete. The top of the pubic crest and the middle of the testicle were taken as the points of measurement. In premature babies, $5 \mathrm{lb}$. $8 \mathrm{oz}$. or less, the figure fixed was $2 \cdot 5 \mathrm{~cm}$. owing to the smaller size of these infants. In fact, in the full-term infant the testicle could almost always be drawn down considerably further than $4 \mathrm{~cm}$. Even in the premature baby of just less than $5 \mathrm{lb} .8 \mathrm{oz}$. a distance of 3,4 or even $5 \mathrm{~cm}$. was usual, but, when the weight was under $4 \mathrm{lb}$., $2.5 \mathrm{~cm}$. appeared to represent a fully descended testicle lying free in the scrotum. Some gradation in measurement is obviously necessary: the criteria mentioned above offer a reasonably reliable estimate of full and incomplete descent.

From another point of view the estimate appears to be valid. If the scrotum is contracted, the testicles may be forced upwards to lie in front of or above the external inguinal ring, but even so they can readily be manipulated and drawn down to reach $4 \mathrm{~cm}$. below the pubic crest. If the same 


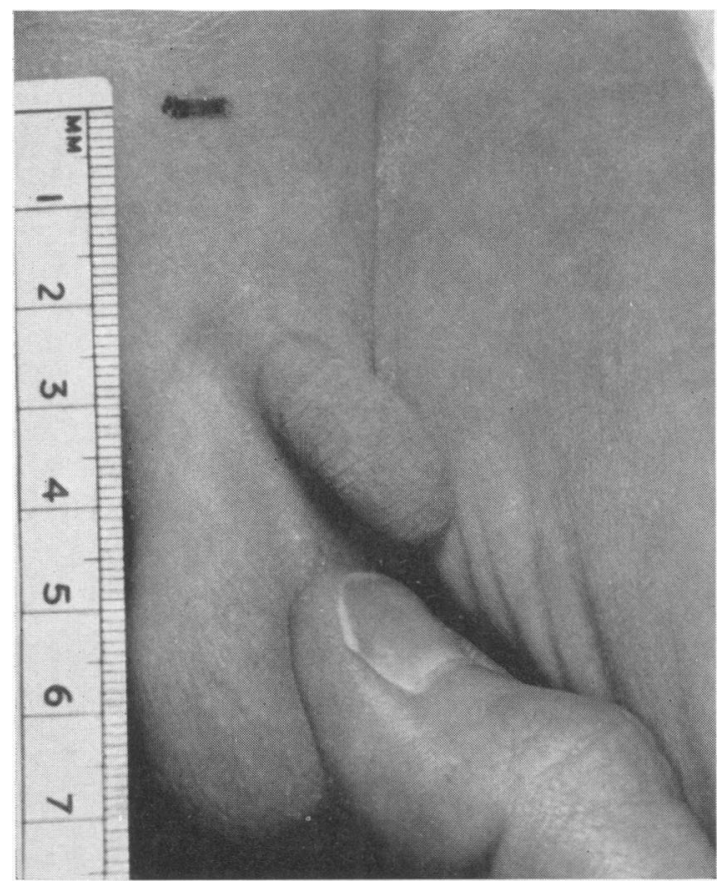

FIG. 3.-The same infant as in Fig. 2. The testicle can be drawn down to a position $6 \mathrm{~cm}$. below the pubic crest.

infant is examined on another occasion when the scrotum is relaxed, the testicles will be found to be lying at the bottom of the scrotum and the distance from the pubic crest will then be about $5 \mathrm{~cm}$.

The condition of the scrotum does, therefore, affect the measurements of the position of the testicles. But once a testicle has been drawn down $4 \mathrm{~cm}$. subsequent examination always reveals that it will lie at, or almost at, the bottom of the relaxed scrotum. In addition, while the testicle is descending there is a certain rigidity of the cord and fixity of the organ; as soon as it has descended it lies free and mobile in the scrotum or can readily be drawn into it.

All cases of incomplete descent were checked on a second occasion and the follow-up was continued until descent was complete. A few cases, in which the testicle is not yet descended, remain under observation.

\section{Results of Examinations at Birth}

More than 1,700 infants were examined. The first 50 are not included in the tables given below because the criterion of what constituted normal descent had not then been established.

Conclusions are drawn from 1,500 consecutive full-term deliveries; the premature births $(5 \mathrm{lb} .8 \mathrm{oz}$. body weight or less) which occurred during this series are classified separately, there being a total of 142.

Table 1 gives the results and shows the number of

TABLE 1

INCIDENCE OF INCOMPLETE DESCENT AT BIRTH

\begin{tabular}{|c|c|c|c|c|c|c|c|}
\hline $\begin{array}{c}\text { State } \\
\text { of } \\
\text { Infant }\end{array}$ & & \multicolumn{3}{|c|}{$\begin{array}{c}\text { Weight } \\
\text { (lb. and oz.) }\end{array}$} & $\begin{array}{l}\text { Cases } \\
\text { Seen }\end{array}$ & $\begin{array}{l}\text { Incom- } \\
\text { plete } \\
\text { Descent }\end{array}$ & $\begin{array}{c}\text { Per- } \\
\text { centage }\end{array}$ \\
\hline Premature & $\cdots$ & $\left\{\begin{array}{l}1 \\
1 \\
2 \\
2 \\
3 \\
3 \\
4 \\
4 \\
5\end{array}\right.$ & $\begin{array}{l}1-1 \\
9-2 \\
1-2 \\
9-3 \\
1-3 \\
9-4 \\
1-4 \\
9-5 \\
1-5\end{array}$ & $\begin{array}{l}8 \\
0 \\
8 \\
0 \\
8 \\
0 \\
8 \\
0 \\
8\end{array}$ & $\begin{array}{r}2 \\
4 \\
5 \\
8 \\
5 \\
11 \\
12 \\
41 \\
54\end{array}$ & $\begin{array}{l}2 \\
4 \\
3 \\
6 \\
3 \\
6 \\
3 \\
7 \\
9\end{array}$ & $\begin{array}{r}100 \cdot 0 \\
100 \cdot 0 \\
60 \cdot 0 \\
75 \cdot 0 \\
60 \cdot 0 \\
54 \cdot 5 \\
25 \cdot 0 \\
17 \cdot 1 \\
16 \cdot 7\end{array}$ \\
\hline Total & . & & & & 142 & 43 & $30 \cdot 3$ \\
\hline Full term & & $\begin{array}{r}5 \\
6 \\
6 \\
7 \\
7 \\
8 \\
8 \\
9 \\
9 \\
10 \\
10 \\
11\end{array}$ & $\begin{array}{l}9-6 \\
1-6 \\
9-7 \\
1-7 \\
9-8 \\
1-8 \\
9-9 \\
1-9 \\
9-10 \\
1-10 \\
9-11 \\
1-11\end{array}$ & $\begin{array}{l}0 \\
8 \\
0 \\
8 \\
0 \\
8 \\
0 \\
8 \\
0 \\
8 \\
0 \\
8\end{array}$ & $\left.\begin{array}{r}130 \\
158 \\
256 \\
284 \\
270 \\
175 \\
135 \\
55 \\
20 \\
10 \\
3 \\
3\end{array}\right\} 401$ & $\left.\begin{array}{r}16 \\
5 \\
8 \\
13 \\
6 \\
1 \\
0 \\
1 \\
1 \\
0 \\
0 \\
0\end{array}\right]^{3} 3$ & 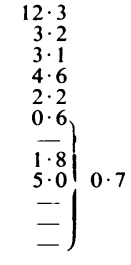 \\
\hline Total & $\cdots$ & & & & $1,499+1 *$ & 51 & $3 \cdot 4$ \\
\hline Grand & & & . & & 1,642 & 94 & $5 \cdot 7$ \\
\hline
\end{tabular}

* The figure +1 denotes a baby of full-term proportions who died shortly after birth from internal haemorrhage but was never weighed.

cases of incomplete testicular descent. The cases are divided according to body-weight at birth.

Any baby recorded as having incomplete descent was found to have either the left, or the right, or both testicles outside the scrotum (according to the measurements described above).

As would be expected, bilateral incomplete descent is found more commonly in premature than in full-term infants. The results are shown in Table 2. There were 94 cases in all and these were taken from the total number of newborn babies examined, 1,500 full-term and 142 premature.

\section{Analysis of Results}

The investigations undertaken and recorded in the accompanying tables show certain important facts which will be enumerated below.

Of all babies in this series, $5.7 \%$ were found to have one or both testicles undescended. In premature babies the incidence was $30.3 \%$; in fullterm deliveries $3 \cdot 4 \%$. 
THE INCIDENCE OF INCOMPLETE DESCENT OF THE TESTICLE AT BIRTH 201

TABLE 2

SIDE AFFECTED IN 94 CASES

\begin{tabular}{|c|c|c|c|c|c|c|c|}
\hline $\begin{array}{l}\text { State of } \\
\text { Infant }\end{array}$ & (lb. & $\begin{array}{l}\text { Veight } \\
\text { and oz }\end{array}$ & & Cases & $\underset{\text { lateral }}{\mathrm{Bi}-}$ & Left & Right \\
\hline Premature .. & $\mid \begin{array}{l}1 \\
1 \\
2 \\
2 \\
3 \\
3 \\
4 \\
4 \\
5\end{array}$ & $\begin{array}{l}1-1 \\
9-2 \\
1-2 \\
9-3 \\
1-3 \\
9-4 \\
1-4 \\
9-5 \\
1-5\end{array}$ & $\begin{array}{l}8 \\
0 \\
8 \\
0 \\
8 \\
0 \\
8 \\
0 \\
8\end{array}$ & $\begin{array}{l}2 \\
4 \\
3 \\
6 \\
3 \\
6 \\
3 \\
7 \\
9\end{array}$ & $\begin{array}{l}2 \\
3 \\
3 \\
5 \\
3 \\
4 \\
1 \\
3 \\
5\end{array}$ & $\begin{array}{c}\overline{-} \\
\overline{1} \\
2 \\
1 \\
2 \\
4\end{array}$ & $\begin{array}{l}-1 \\
- \\
- \\
1 \\
2\end{array}$ \\
\hline Total .. & & & & 43 & 29 & 10 & 4 \\
\hline Full term & $\left\{\begin{array}{r}5 \\
6 \\
6 \\
7 \\
7 \\
8 \\
8 \\
9 \\
9 \\
10 \\
10 \\
11\end{array}\right.$ & $\begin{array}{l}9-6 \\
1-6 \\
9-7 \\
1-7 \\
9-8 \\
1-8 \\
9-9 \\
1-9 \\
9-10 \\
1-10 \\
9-11 \\
1-11\end{array}$ & $\begin{array}{l}0 \\
8 \\
0 \\
8 \\
0 \\
8 \\
0 \\
8 \\
0 \\
8 \\
0 \\
8\end{array}$ & $\begin{array}{r}16 \\
5 \\
8 \\
13 \\
6 \\
1 \\
-1 \\
1 \\
- \\
-\end{array}$ & $\begin{array}{l}5 \\
3 \\
2 \\
2 \\
1 \\
1 \\
- \\
- \\
- \\
- \\
-\end{array}$ & $\begin{array}{r}5 \\
2 \\
4 \\
8 \\
3 \\
- \\
- \\
1 \\
- \\
-\end{array}$ & $\begin{array}{l}6 \\
2 \\
3 \\
2 \\
- \\
-1 \\
- \\
- \\
-\end{array}$ \\
\hline Total .. & & & & 51 & 14 & 23 & 14 \\
\hline \multicolumn{2}{|c|}{ Grand total } & $\ldots$ & . & 94 & 43 & 33 & 18 \\
\hline
\end{tabular}

Descent was most common when the baby was between 3 and $6 \mathrm{lb}$. weight. It was rare when the weight was less than $2 \mathrm{lb}$., although one of the stillborn babies in this series, weighing $1 \mathrm{lb} .12 \mathrm{oz}$. , had the left testicle fully descended $(2 \cdot 5 \mathrm{~cm}$. below the pubic crest). Descent was almost always complete in babies more than $8 \mathrm{lb}$.

The incidence of incomplete descent fell steadily with the increasing weight of the baby at birth. In those over $8 \mathrm{lb}$. only $0.7 \%$ had the deformity.

In Table 1 no account has been taken of twin deliveries. There were in the series 19 twin boys and 20 cases of boy and girl twins, thus accounting for 58 boys in all. A comparative analysis is made below (Table 3) of the incidence of incomplete testicular descent in twin births and single births.

The numbers of infants involved in the twin series are too small to allow for any significant deductions to be made.

Bilateral incomplete descent was, of course, commoner in premature babies: the relative incidence is shown in Table 4.

The figures also suggest (Table 2) that descent took place a little later on the left side than on the right, 33 cases compared with 18 . This inference was confirmed during routine examination of normal infants when the left testicle at birth was more often found to lie a little above the right than the reverse (in contrast to the adult position).

\section{Follow-up}

A follow-up of cases of undescended testicle could usefully be continued for many years-at least until
TABLE 3

TWIN AND SINGLE BIRTHS COMPARED

\begin{tabular}{|c|c|c|c|c|}
\hline Maturity & Birth & $\begin{array}{l}\text { Cases } \\
\text { Seen }\end{array}$ & $\begin{array}{l}\text { Incomplete } \\
\text { Descent }\end{array}$ & $\begin{array}{c}\text { Per- } \\
\text { centage }\end{array}$ \\
\hline$\overline{\text { Premature } \quad . .}$ & $\left\{\begin{array}{l}\text { Twin } \\
\text { Single }\end{array}\right.$ & $\begin{array}{r}30 \\
112\end{array}$ & $\begin{array}{r}7 \\
36\end{array}$ & $\begin{array}{l}23 \cdot 3 \\
32 \cdot 2\end{array}$ \\
\hline Total .. & & 142 & 43 & $30 \cdot 3$ \\
\hline Full term & $\left\{\begin{array}{l}\text { Twin } \\
\text { Single }\end{array}\right.$ & $\begin{array}{r}28 \\
1,472\end{array}$ & $\begin{array}{r}3 \\
48\end{array}$ & $\begin{array}{r}10 \cdot 7 \\
3 \cdot 3\end{array}$ \\
\hline Total .. & & 1,500 & 51 & $3 \cdot 4$ \\
\hline
\end{tabular}

TABLE 4

INCIDENCE OF BILATERAL INCOMPLETE DESCENT

\begin{tabular}{cc|c|c|c}
\hline Maturity & & Cases & Bilateral & Percentage \\
\hline Premature &. & 43 & 29 & 67.4 \\
Full term .. &. & 51 & 14 & 27.5 \\
\hline Total .. &. & 94 & 43 & $45 \cdot 7$ \\
\hline
\end{tabular}

after puberty. There is still doubt as to whether descent can take place up till adolescence, and if so, how often.

The result of watching newborn infants showed that the testicle often moved down during the first few days of life. Of the 94 cases undescended at birth, 23 were either stillborn or died in the neonatal period and almost all of these were premature. Of the remaining 71 , the testicle descended in 38 $(54 \%)$. Thirty-three are still being watched and in some of these the transition has taken place during subsequent months. Table 5 shows the maturity of the babies in whom the testicle descended within one month.

TABLE 5

DESCENT OF TESTICLE IN FIRST MONTH

\begin{tabular}{|c|c|c|c|c|c|}
\hline $\begin{array}{c}\text { State } \\
\text { of } \\
\text { Infant }\end{array}$ & Number & Died & $\underset{\text { Up }}{\text { Followed }}$ & $\begin{array}{l}\text { Descent } \\
\text { in One } \\
\text { Month }\end{array}$ & $\begin{array}{c}\text { Per- } \\
\text { centage }\end{array}$ \\
\hline $\begin{array}{l}\text { Premature } \\
\text { Full term }\end{array}$ & $\begin{array}{l}43 \\
51\end{array}$ & $\begin{array}{r}20 \\
3\end{array}$ & $\begin{array}{l}23 \\
48\end{array}$ & $\begin{array}{l}14 \\
24\end{array}$ & $\begin{array}{l}60 \cdot 9 \\
50 \cdot 0\end{array}$ \\
\hline Total & 94 & 23 & 71 & 38 & $53 \cdot 5$ \\
\hline
\end{tabular}

In the 38 infants in whom the testicle descended it reached the same low position as the opposite one and appeared to be of the same size and consistency. There was therefore a normal descent which was delayed beyond birth.

It is evident that the passage of the testicle from the abdomen into the bottom of the scrotum was normally rapid, taking only a few days or possibly two or three weeks. In full-term infants the testicle was very seldom in a half-way position (certainly less than $3.4 \%$ ); it was either down or up. In the very few cases where it could only be drawn half-way down the descent was completed during the next 
day or two. This rapidity of descent was also noticed in premature infants but movement often did not start until some days after birth.

\section{Summary}

Over 1,700 newborn male infants have been examined in a maternity unit in order to find out the incidence of incomplete descent of the testicle. In full-term deliveries it was $3.4 \%$ and in those born prematurely $30.3 \%$.

An arbitrary definition of incomplete descent has been made. If this should become standard, the figures produced by different workers would then be comparable.
The babies have been classified according to weight. Descent was most common when the baby was between $3 \mathrm{lb}$. and $6 \mathrm{lb}$.

A follow-up of all cases of incomplete descent showed that in more than $50 \%$ the testicle reached the scrotum during the first month of life.

I wish to thank Dr. H. V. L. Finlay, physician in charge of our Paediatric Unit, for his enthusiastic encouragement and his stimulating criticism while this investigation was carried out.

\section{REFERENCES}

Counseller, V. S. (1933), J. Urol 30, 327

Debenham, R. K and Baines, G. (1954) In Diseases of Infancy and Childhood (ed. Parsons, L. and Barling, S.), 2nd ed., Vol. 2, p. 1179. Oxford

Deming, C. L. (1952). J. Crol., 68, 354.

Hofstatter, R. (1912). Klin. Jb., 26, 155. 